\title{
Gastrointestinal emergency care during the COVID-19 pandemic: rapid communication
}

\author{
DCarine Leite ${ }^{1}$ \\ DEduardo Neubarth Trindade ${ }^{2}$ \\ (iDLeonardo Wagner Grillo ${ }^{1}$ \\ (D) Manoel Roberto Maciel Trindade ${ }^{2,3}$
}

1. Departamento de Gastroenterologia e Esdoscopia, Hospital Moinhos de Vento, Porto Alegre, RS. Brasil.
2. Departamento de Cirurgia Geral, Hospital Moinhos de Vento, Porto Alegre, RS, Brasil. 2. Departamento de Cirurgia Geral, Hospital Moinhos de Vento, Porto Alegre, RS, Brasil.
3. Universidade Federal do Rio Grande do Sul (UFRGS), Porto Alegre, RS, Brasil.

\section{SUMMARY}

OBJECTIVE: Social distancing during the COVID-19 pandemic has been associated with a decrease in the search for medical care. Highrisk patients have avoided hospital environments fearing infection. We hypothesize that there was also a decrease in the search for medical care related to gastrointestinal emergencies. The aim of this study is to evaluate the frequency of consultations for severe gastrointestinal emergencies during and before the months of the pandemic.

METHODS: This was a transversal study. The inclusion criteria were cases of consultation in the emergency department for gastrointestinal diseases that required hospitalization, from January to April, from 2015 to 2020. The pediatric population (under age 12) was excluded.

RESULTS: A total of 2,457 cases of cases was included. The number of emergency hospitalizations for gastrointestinal cases decreased during the first four months of 2020: 108, 112, 82, and 77, respectively. Comparing April of 2020 with previous years, there was a lower than expected number of cases during the social distancing period $(P=0.002)$.

CONCLUSION: This study reports a pronounced decrease in consultations for severe gastrointestinal emergencies during the pandemic Governments and society should be aware that health crises do not halt the natural occurrence of noninfectious diseases; otherwise, an increase in mortality from these morbidities may arise.

KEYWORDS: Coronavirus Infections. Emergencies. Emergency Medical Services. Gastrointestinal tract.

\section{INTRODUCTION}

The pandemic caused by the severe acute respiratory syndrome coronavirus 2 (COVID-19) ${ }^{1}$ has generated large-scale social and behavioral changes, mostly because of lockdown and social distancing ${ }^{2}$. The advice to stay home except for essential activities has been associated with a decrease in the demand for medical care for symptoms not related to COVID-19.
High-risk patients have avoided hospital environments fearing infection. In a study conducted in Spain, it was observed a decrease of fifty percent in emergency coronary interventions during this period $^{3}$. In China, there was a four-fold increase of the time to seek medical care for myocardial infarction in comparison with the previous years ${ }^{4}$. A $65.4 \%$

DATE OF SUBMISSION: 23-Jun-2020

DATE OF ACCEPTANCE: 11-Jul-2020

CORRESPONDING AUTHOR: Carine Leite

Rua Ramiro Barcelos, 910, Hospital Moinhos de Vento, Porto Alegre, RS, Brasil - 90035-000

Tel: +55 513211-2117

E-mail: carineleite@hotmail.com 
decrease in emergency surgery was observed in another study in Spain ${ }^{5}$.

We hypothesize that there was also a decrease in the search for medical care related to gastrointestinal emergencies. To that purpose, we conducted a study in a tertiary hospital to evaluate the frequency of consultations for severe gastrointestinal emergencies during and before the months of the pandemic.

\section{METHODS}

This was a transversal study. A data survey of consultations in the emergency department that required hospitalization, from January to April, from 2015 to 2020 , was conducted. The period of social distancing in the city was from March $18^{\text {th }}$ to April $30^{\text {th }}$. A query in the system of hospitalizations due to emergency, based on the International Classification of Diseases $11^{6}$, was conducted. All cases of gastrointestinal emergencies were included. The pediatric population (under age 12) was excluded. The patients' data were obtained from the computer system records. The Chi-square test was used to compare months and adjust residual analysis to detect categories with higher and lower than expected frequencies (+/- 1.96). The statistics software used was IBM SPSS version 20.0.

This study was approved by the Ethical Committee of the Hospital (number 4.044.906) and is in accordance with Resolution 466/2012 of the National Health Council of the Ministry of Health.

\section{RESULTS}

A total of 2,457 cases was included. The majority were women $(53 \%)$, and the mean age was 53.5 years ( $\mathrm{DP}=22.6)$. The most common morbidity was acute appendicitis (21.7\%), followed by acute cholecystitis (7.3\%), and diverticulitis (5.7\%). The number of consultations each month are detailed in Table 1.

TABLE 1. NUMBER OF CONSULTATIONS FOR SEVERE GASTROINTESTINAL EMERGENCIES FROM JANUARY TO APRIL, FROM 2015 TO 2020.

\begin{tabular}{l|l|l|l|l|l|l|l} 
Year \\
\hline Month & 2015 & 2016 & 2017 & 2018 & 2019 & 2020 & Total \\
\hline 1 & 74 & 80 & 98 & 109 & 123 & 108 & 592 \\
\hline 2 & 97 & 113 & 95 & 107 & 92 & 112 & 616 \\
\hline 3 & 114 & 103 & 99 & 104 & 100 & 82 & 602 \\
\hline 4 & 91 & 114 & 121 & 126 & 118 & 77 & 647 \\
\hline Total & 376 & 410 & 413 & 446 & 433 & 379 & 2457 \\
\hline
\end{tabular}

The emergency hospitalizations for gastrointestinal cases decreased during the first four months of 2020: 108, 112, 82, and 77, respectively. Comparing April of 2020 with previous years, there was a lower than expected number of cases during the social distancing period (see Figure 1). For example, appendicitis cases in April 2015 to 2020 were: 33, 25, 22, 24, 36 , and 13.

FIGURE 1. FREQUENCY OF CONSULTATIONS FOR SEVERE GASTROINTESTINAL EMERGENCIES IN APRIL FROM 2015 TO 2020. THE LINE INDICATES THE EXPECTED FREQUENCY OF CASES IN THE MONTH AND YEAR BELLOW (CHI-SQUARE TEST, $\mathrm{P}=0.002$; ADJUSTED RESIDUALS: $-1,0.7,1.5,1.0,0.5,-2.9)$.

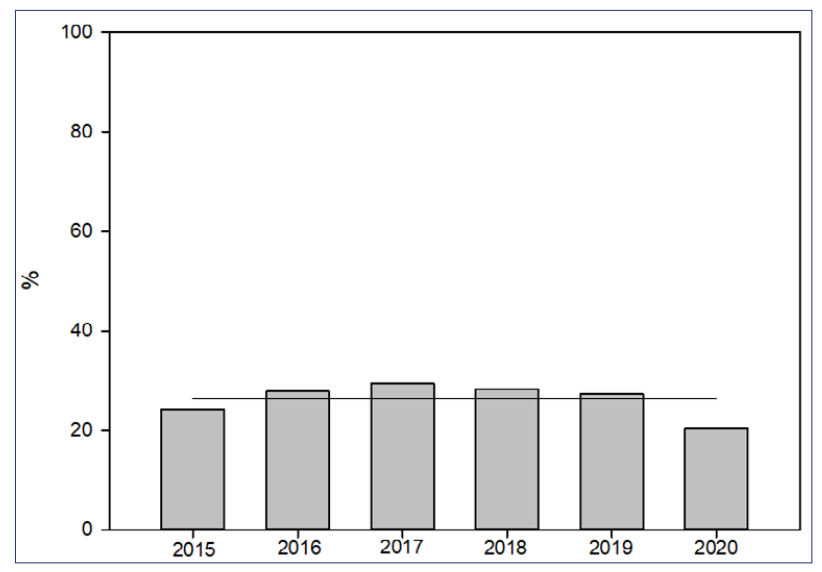

\section{DISCUSSION}

This study reports a pronounced decrease in consultations for severe gastrointestinal emergencies during the pandemic and social distancing. To our knowledge, this is the first publication regarding the consequences of COVID-19 both in clinical and surgical gastroenterology. There is a similar study by Cano-Valderrama et al. ${ }^{5}$ in Spain, but they analyzed only 173 surgical cases. They reported a $65.4 \%$ decrease in emergency interventions $(\mathrm{P}<0.001)^{5}$.

There is a limitation in this analysis because it is based in a single hospital. However, it brings worrying issues. We do not know the outcomes of patients who were not treated for potentially life-threatening conditions, such as acute appendicitis.

\section{CONCLUSION}

New pandemics may emerge. Governments and society should be aware that these health crises do 
not halt the natural occurrence of noninfectious diseases; otherwise, an increase in mortality from these morbidities may arise.

\section{Author's Contribution}

CL conceptualized the article, obtained Ethical approval, collected and analyzed the data, drafted the manuscript, reviewed and revised the manuscript, approved the final draft as submitted, and reviewed the final manuscript for resubmission. ENT, LWG, and MRMT analyzed the data, drafted the manuscript, reviewed and revised the manuscript, approved the final draft as submitted.

\section{Conflict of Interest}

The authors disclose no conflicts.

\section{RESUMO}

OBJETIVO: O distanciamento social durante a pandemia por COVID-19 tem sido associado a uma redução na busca por atendimento médico. Pacientes de alto risco têm evitado ambiente hospitalar com receio de infectar-se. Nossa hipótese é de que houve também uma redução no atendimento médico a emergências gastrointestinais. O objetivo deste estudo é avaliar a frequência de consultas por emergências gastrointestinais graves durante e antes da pandemia.

MÉTODOS: Estudo transversal. O critério de inclusão foram casos de consulta em emergência por patologia gastrointestinal que tenham requerido hospitalização, de janeiro a abril dos anos 2015 a 2020. A população pediátrica foi excluída.

RESULTADOS: Um total de 2.457 casos foi incluído. O número de hospitalizações via emergência durante os primeiros quatro meses de 2020 foi: 108, 112, 82 e 77, respectivamente. Comparando abril de 2020 com anos anteriores, houve um número de atendimentos abaixo do esperado $(p=0,002)$.

CONCLUSÃO: Este estudo relata uma redução pronunciada em atendimentos por emergências gastrointestinais graves na pandemia. Governos e sociedade devem estar cientes de que tais crises de saúde não interrompem a ocorrência natural de doenças não infecciosas, do contrário poderá ocorrer um aumento na mortalidade por outras morbidades.

PALAVRAS-CHAVE: Infecções por coronavírus. Emergências. Serviços médicos de emergência. Trato gastrointestinal.

\section{REFERENCES}

1. Huang C, Wang Y, Li X, Ren L, Zhao J, Hu Y, et al. Clinical features of patients infected with 2019 novel coronavirus in Wuhan, China. Lancet. 2020;395(10223):497-506.

2. Tang B, Wang X, Li Q, Bragazzi NL, Tang S, Xiao Y, et al. Estimation of the transmission risk of the 2019-nCoV and its implication for public health interventions. J Clin Med. 2020;9(2):462.

3. Rodríguez-Leor O, Cid-Álvarez B, Ojeda S, Martín-Moreiras ], Rumoroso IR, et al. Impacto de la pandemia de COVID-19 sobre la actividad asistencial en cardiología intervencionista en España. REC Interv Cardiol. 2020;2:82-9.
4. Tam CF, Cheung KS, Lam S, Wong A, Yung A, Sze M, et al. Impact of coronavirus disease 2019 (COVID-19) outbreak on ST-segment-elevation myocardial infarction care in Hong Kong, China. Circ Cardiovasc Qual Outcomes. 2020;13(4):e006631.

5. Cano-Valderrama O, Morales X, Ferrigni Cl, Martín-Antona E, Turrado V, García A, et al. Reduction in emergency surgery activity during COVID-19 pandemic in three Spanish hospitals. Br J Surg. 2020;107(8):e239.

6. World Health Organization. International classification of diseases. $11^{\text {th }}$ revision. Genebra: World Health Organization; 2018. [cited 2020 Jun 3]. Available from: https://icd.who.int/en 